\title{
Editorial
}

\section{Qualidade, transformações e fortalecimento científico no Brasil e na América Latina}

Quality, transformations and scientific enhancement in Brazil and Latin America

\section{Calidad, transformaciones y fortalecimiento científico en Brasil y América Latina}

\author{
Glauber Eduardo de Oliveira Santos ${ }^{1}$, Leandro Benedini Brusadin² \\ ${ }^{1}$ Editor-chefe - Revista Brasileira de Pesquisa em Turismo (RBTUR), São Paulo, SP, Brasil. \\ 2 Editor Associado - Revista Brasileira de Pesquisa em Turismo (RBTUR), São Paulo, SP, Brasil.
}

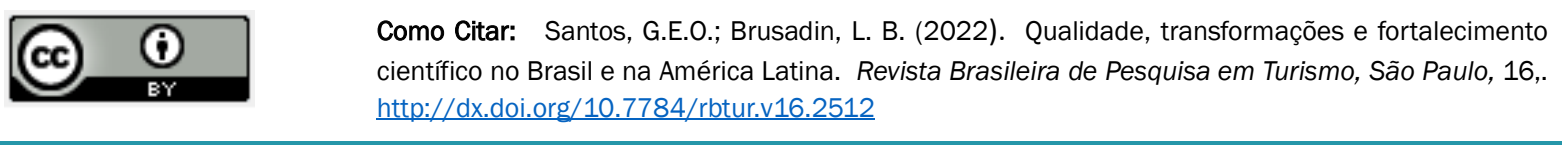

Em 2021, a Revista Brasileira de Pesquisa em Turismo (RBTUR) completou 15 anos de uma história bem sucedida de contribuições significativas para a difusão científica. Criada e mantida pela ANPTUR desde 2007, a revista tem publicado artigos entre os mais relevantes da área de Turismo no Brasil, os quais atraem leitoras e leitores de diversas áreas do conhecimento, impactando ideias e práticas. Atualmente, a RBTUR ocupa posição de destaque no cenário científico nacional, sendo amplamente reconhecida por seus pares.

Frente à veloz dinâmica da sociedade e da academia na contemporaneidade, a RBTUR não parou de evoluir. Nos últimos anos, a revista adotou novas políticas editoriais, fortaleceu a definição de seu escopo, criou a sessão "Perspectivas", voltada para textos excepcionais, e ampliou o reconhecimento às diferentes perspectivas epistemológicas. Ademais, passou a incentivar as práticas de ciência aberta e reforçou seu compromisso com o desenvolvimento da pesquisa em turismo no Brasil e na América Latina, frente ao necessário diálogo com as especialidades de nosso continente.

Neste exato momento, a RBTUR traz duas novidades de relevância para sua política editorial e a organização de suas temáticas.

1. Adesão ao sistema de publicação em fluxo contínuo, modo recomendado para revistas online e que representa a tendência das publicações científicas de acesso aberto no mundo. Dessa maneira, a partir da edição de 2022, a revista passa a publicar um único número por ano. Os artigos serão publicados logo ao final do processo editorial, sem a necessidade de serem colocados em espera para publicação. Diante disto, as publicações deverão ganhar celeridade, favorecendo a rápida difusão e impacto do conhecimento produzido, bem como antecipando o reconhecimento das autoras e autores. 
2. Outro avanço é a criação de duas novas seções para facilitar a organização, a comunicação e a leitura. Dada a diversidade das pesquisas em turismo, acreditamos que o agrupamento irá favorecer a sinergia entre trabalhos mais próximos, assim como evidenciar o espaço para diferentes frentes e formas de pesquisa. Com a segmentação temática, a RBTUR pretende acolher com maior clareza e transparência toda a sorte de pesquisas que versam sobre o turismo.

A seção Turismo e Sociedade publicará artigos relativos às questões sociais, culturais e ambientais referentes ao uso turístico em diferentes tempos e espaços. Esse agrupamento inclui trabalhos científicos sobre turismo em diálogo com as ciências humanas e sociais, tais como história, sociologia, educação, geografia, artes, antropologia, arquitetura e urbanismo, museologia, gastronomia, letras, psicologia, filosofia, lazer, mobilidade e hospitalidade.

A seção Gestão do Turismo publicará artigos voltados para temas relacionados à administração de destinos e negócios turísticos. Este conjunto, naturalmente, inclui trabalhos sobre diversos aspectos desses elementos, tais como políticas públicas, administração pública e de empresas, economia, marketing, ciências comportamentais, tecnologia, planejamento territorial e tantos outros.

Com essas mudanças, a RBTUR espera fortalecer sua contribuição para o desenvolvimento e a difusão do conhecimento científico e acadêmico em turismo, especialmente no Brasil e na América Latina.

\section{Informações dos autores}

\section{Glauber Eduardo de Oliveira Santos}

E-mail: glauber.santos@usp.br

ORCID: http://orcid.org/0000-0001-8731-101X

Leandro Benedini Brusadin

E-mail: leandro@turismo.ufop.br

ORCID: http://orcid.org/0000-0002-2778-2095 